\title{
Reduced Air Pollution with Electrified Vehicles for Fulfilling Children's Health Right in the Fourth Industrial Revolution
}

\author{
David Anggara Putra
}

\author{
Department of Child Health, Faculty of Medicine, Universitas Sebelas Maret/RSUD Dr. Moewardi, Surakarta, Indonesia \\ *Corresponding author. Email: davidanggara.dr@gmail.com
}

\begin{abstract}
Rapid industrial growth is followed by environmental problems in soil, air and water, especially in developing countries. Extensive air pollution caused by vehicle exhausts combined with industrial emissions. Air pollution is a significant challenge to the stability of the earth's systems, spurring global climate change, destroying ecosystems and threatening human health. Air pollution has the potential to affect almost every organ in the body. Children are more prone to illnesses caused by air pollution. They are especially susceptible throughout prenatal development and the first few phase of life, when their lungs, organs, and brains are still growing. Electric vehicles have the potential to reduce greenhouse gases and other pollutants due to the absence of exhaust emissions. Indonesia is committed to reducing greenhouse gas emissions and the availability of clean air in accordance with the Sustainability Development Goals (SDGs) 2030. Finally, studies indicate that less air pollution may benefit for physical and cognitive development of pediatric population. The government needs to encourage as well as to synergize with various ministries, businesses and industries, nongovernmental organizations to accelerating the achievement of emissions reduction targets and creating cleaner air.
\end{abstract}

\section{Keywords: Electric vehicles, air pollution, child health, fourth industrial revolution}

\section{INTRODUCTION}

In recent years technological and industrial advances have grown very quickly. Advances in technology have the potential to improve and simplify people's lives but also raise some concerns. [1]. The advancement of technology in synergy followed by the industrial revolution. The industrial revolution forced the world to change with a transformation in the business sector, economic and people's lives. These changes have had a huge effect on the world and continue to this day[2]. In fact, rapid industrial growth is followed by environmental problems in soil, air and water, especially in developing countries. Extensive air pollution caused by vehicle exhausts combined with industrial emissions. Ammonia loads and high concentrations of heavy metals are enough to cause major threat of life down-river from industrial area [3].
Air pollution is a significant challenge to the stability of the earth's systems, spurring global climate change, destroying ecosystem, and threatening human health. Based on data from OCED, Indonesia's air pollution exposure is relatively the same as neighboring countries such as Singapore and Malaysia and far below other ASEAN countries such as Myanmar and Thailand but still above the minimum standards set by OCED [4]. Exposure to air pollution is thought to be responsible for $16 \%$ of global deaths primarily in at-risk populations such as in children [5]. It has been reported that about 7,000,000 individuals worldwide die due to polluted air. WHO reports that 9 out of 10 inhale air surpassing WHO recommendation which contains significant degree of contaminants, in which, low as well as middle income countries were most affected. [6]. 
Exposure to air contamination is an overlooked health problems for children in the world. Children can be exposed to pollution both indoors and outdoors. There is a lot of evidence to suggest effects on children's health due to exposure to air pollution, including adverse birth outcomes, infant mortality, neurodevelopment, childhood obesity, breathing function and some respiratory problems. In 2016, air pollution was responsible for 4.2 million deaths and nearly 300,000 were underfives. WHO data shows in ASEAN countries the mortality rate due to air pollution in children aged less than 5 years was 75 per 100,000 while at the age of 5-14 years was 2.5 per 100,000 [7].

Some contributors related to poor air quality in Indonesia include mining, gas and oil industry, vehicle assembly, vehicle emissions and forest fires [8]. One that has the potential to reduce transportation emissions is the use of electric vehicles rather than internal combustion engine vehicles (ICEVs). We aim to present the latest literature on electric vehicles and their potential to improve children's health related to air pollution.

\section{METHODS}

This study is a literature review using the data from Google scholar, Web of Science, PubMed and Scopus. With the keywords "electric vehicle" and "air pollution and health", "ambient air pollution" and "children health." All articles published in English and Bahasa were included and we excluded abstract only, reader's letter, reviews of publish studies, and pre-proof journal.

\section{LITERATUR REVIEW}

\subsection{Air Pollution and Child Health}

The air quality in Indonesia has been changed over the past two decades. In 2016 ndonesia is one of the 20 most polluted countries, in fact in 1998, Indonesia is the cleanest country [9] This makes Indonesia one of the nations with the most elevated contamination levels and is positioned eighteenth out of 220 nations in the AQLI Index [10].

Exposure to air pollutants can lead to health problems. Air pollution has the potential to affect almost every organ in the body. As their sizes are very small, some air pollutants can penetrate into bloodstream mediated by lungs and circulate throughout the entire body causing inflammation, oxidative stress, immunosuppression, and mutagenicity in cells throughout our body, impacting the lungs, heart, brain, and inducing systemic inflammation and carcinogenicity, which eventually prompt infection [11]. Air pollution is directly linked to fatal illnesses. A study in 2012 revealed that polluted air was responsible for one in 8 fatalities worldwide - or around 7 million people [12]. Globally, 600,000 of them were under-fives. Each year, nearly one million children die because of pneumonia, more than half of them correlate with air pollution directly [13].

Children are more often affected by diseases caused by air pollution. Children are especially susceptible throughout prenatal development and the first few years of life, when their lungs, organs, and brains are still developing [14]. They breathe quicker than adults, allowing them to take in more air and, as a result, breath in more contaminants. Children more often play in open spaces, they are more potential to have a direct contact with some pollutants that reach peak concentration [11].

Because life expectancy of children is longer than that of adults, latent illness process has more time to manifest and impact on health negatively. Young bodies, particularly their lungs, are rapidly growing, making them more sensitive to pollution-induced inflammation and other harm [15]. Even at modest levels of exposure, the growth of lung function can be disrupted because it is infected by existing pollutants, the evidenced by several studies that already exist [16] Several studies have shown strong evidence that air pollution exposure during prenatal period relates to undermined lung growth and function of the children. Numerous studies offer compelling evidence that exposure to air contaminants like $\mathrm{PM} 2.5, \mathrm{NO} 2$ and $\mathrm{O} 3$ is related to pneumonia and other respiratory infections such as asthma or bronchitis in young children [17].

While in the womb, children can be infected with pollutants through their mothers. Numerous studies have shown a significant correlation between exposure to ambient air pollution and abnormal birth outcomes, particularly exposure to $\mathrm{PM}, \mathrm{SO} 2, \mathrm{NO} 2$, $\mathrm{O} 3$ and $\mathrm{CO}$. There is compelling evidence that exposure to ambient PM is associated with low birth weight [18] There is also growing evidence that maternal exposure, especially to fine PM, raises the risk of premature delivery. There is emerging evidence for correlation between exposure to air contaminants and other outcomes, such as infants born small for gestational age and even infant mortality [18][19][20]. 


\subsection{Electric Vehicles on Fourth Industrial Revolution}

The $1^{\text {st }}$ revolution in industry used water and steam power to mechanize production. The Second used electric power to create mass production. The Third used electric and information technology to operate production. The combination of technology between the physical, digital and biological indicated that the industrial revolution is getting more advanced, it has been started from the third industrial revolution. [21]. Energy and mobility are the double pillars of these transformations, and these two will necessitate extreme adaptation to meet the demographic and economic growth without augmenting congestion and pollution. The query is whether stakeholder and business leaders can utilize and integrate them in ways which optimize their benefits for cost efficiency, economic growth and environment. This current Industrial Revolution propounds an extraordinary prospect [22].

This current Industrial Revolution (4IR) in energy and mobility systems is modifying. Electric vehicles use a replacement battery to run the engine, and electric motor vehicles use an internal combustion engine replacement. Plug-in hybrid electric vehicles (PHEVs) utilize both patrol and electricity as fuel sources [23]. Electric vehicles have the potential to reduce greenhouse gases and other pollutants due to the absence of exhaust emissions. A few investigations have been led to take a gander at the impacts of electric vehicles on public health and show promising results related to lowering pollutant levels [24]. But some other studies have shown different results. Electric vehicles can indeed reduce exhaust emissions but pollutants resulting from the production process from electric vehicles. A study from the Massachusetts Institute of Technology Energy Initiative found that the production of batteries and fuels of electric vehicles produces higher emissions than the production of the car itself. But overall the total emissions generated by batterybased vehicles are lower compared to internal combustion engines. [25], [26].

Although worldwide sales of electric vehicles are still small, in the last six years growth has increased. In line with the Paris Agreement's goals on reducing greenhouse gas emissions and air pollution, several countries have implemented policies related to electricity vehicles [27]. Indonesia is also one of the countries that has always been committed to reducing emissions and the availability of clean air in accordance with the Sustainability Development Goals (SDGs) 2030. In the Nationally Determined
Contribution (NDC) Indonesia itself commits to reduce greenhouse gas emissions by $29 \%$ and $41 \%$ with international assistance [28]. So far Indonesia through various ministries has issued regulations to support the electric vehicle ecosystem in Indonesia. Some of these regulations are 1) Government Regulation No. 72/2019, 2) Presidential Regulation No. 55/2019, 3) Regulation of the Minister of Energy and Mineral Resources No. 13/2020, 4) Regulation of the Minister of Transportation No. 45/2020, 5) Regulation of the Minister of Home Affairs No. $8 / 2020,6)$ Regulation of the Minister of Industry No. 27/2020 and No. 28/2020 [29].

Adiatma et al study from the Institute for Essential Services Reform (IESR) published in 2020 provides a summary of the role of electric vehicles in decarbonization in the land transportation sector. The study provides conclusions and policies for the success and implementation of Indonesia's commitment in reducing emissions by 2030, including a reduction in the price of EVs through tax incentive schemes and the like, non-financial incentives such as odd-even free or parking-free, the construction of extensive public electricity delivery infrastructure, issuing policies such as greenhouse gas emission reduction obligations or ban on the sale of conventional vehicles no later than 2035, as well as the construction of an electric vehicle industry that includes the battery industry, electric engines, power converters and vehicle manufacturing materials or assembly [28]

\section{CONCLUSION}

The advantages of decreasing air pollution extend well beyond child health. Decreased air pollution has resulted in improvement of life expectancy in children. WHO estimates that fulfilling global air quality guidelines for PM2.5 could prevent 2.1 million deaths per years. It could also improve health body of millions more, help to reduce the incidence of acute or chronic respiratory infections in children, and lower complications in pregnant woman. Finally, studies indicate that less air pollution may benefit for children's growth and development, permitting them to lead longer and more useful lives. The government needs to encourage and synergize with various ministries, businesses and industries and nongovernmental organizations to accelerate the implementation of decarbonization through electric vehicles. Foreign cooperation is also needed in accelerating the achievement of emissions reduction targets and creating cleaner air. 


\section{AUTHORS' CONTRIBUTIONS}

The author confirms that he is solely responsible for the idea and study design, data collection, analysis and interpretation of the outcomes, and preparation of this paper.

\section{ACKNOWLEDGMENTS}

My special thanks go to Dr. Sunny, S.H., M.H. and Principal Dr. Muh. Jamin, S.H., M.Hum. who gave me an opportunity to do this project and gave me a lot of new things that I really appreciate.

\section{REFERENCES}

[1] E. K. Zervoudi, "Fourth Industrial Revolution: Opportunities, Challenges, and Proposed Policies," Ind. Robot. - New Paradig., pp. 1-25, 2020, doi: 10.5772/intechopen.90412.

[2] National Geographic, "Industrialization, Labor, and Life," 2020. /nationalgeographic.org/article/industrializati on-labor-and-life/7th-grade/.

[3] H. Magsi, "Industrialization, Environment and Pollution," Dipl. Insight, vol. 7, no. 9, pp. 24-26, 2014.

[4] OCED, "Air pollution exposure (indicator)," 2021. https://data.oecd.org/air/air-pollutionexposure.htm (accessed Sep. 25, 2021).

[5] A. L. Power et al., "Monitoring Impacts of Urbanisation and Industrialisation on Air Quality in the Anthropocene Using Urban Pond Sediments," vol. 6, no. September, pp. 1-18, 2018, doi: 10.3389/feart.2018.00131.

[6] WHO, "Air Pollution," 2021. https://www.who.int/health-topics/airpollution\#tab=tab_1 (accessed Sep. 25, 2021).

[7] WHO, "Air Pollution and Child Health," Who, vol. 113, p. 32, 2018, [Online]. Available:

http://pediatrics.aappublications.org/content/1 13/Supplement_3/1037.full.html.

[8] IAMAT, "Indonesia General Health Risk: Air Pollution," 2020. https://www.iamat.org/country/indonesia/risk /air-pollution\# (accessed Sep. 25, 2021).

[9] M. Greenstone and Q. (Claire) Fan, "Kualitas Udara Indonesia yang Memburuk dan Dampaknya terhadap Harapan Hidup," Air
Qual. Life Index, pp. 1-10, 2019, [Online]. Available: https://aqli.epic.uchicago.edu/wpcontent/uploads/2019/03/Indonesia.Indonesia n.pdf.

[10] P2PTM Kemenkes RI, "Polusi Udara Pangkas Usia Penduduk Indonesia Hingga 5 Tahun," 2018. http://p2ptm.kemkes.go.id/artikelpenyakit/polusi-udara-pangkas-usiapenduduk-indonesia-hingga-5-tahun (accessed Sep. 25, 2021).

[11] WHO, "Air quality and health," 2021. https://www.who.int/teams/environmentclimate-change-and-health/air-quality-andhealth/health-impacts (accessed Sep. 25, 2021).

[12] WHO, "7 million premature deaths annually linked to air pollution," 2014. https://www.who.int/news/item/25-03-20147-million-premature-deaths-annually-linkedto-air-pollution (accessed Sep. 25, 2021).

[13] WHO HAP report, "Burden of disease from household air pollution for 2012. Summary of results," World Heal. Organ., vol. 35, no. February, p. 3, 2014, [Online]. Available: http://www.who.int/phe/health_topics/outdoo rair/databases/FINAL_HAP_AAP_BoD_24 March2014.pdf.

[14] D. V Bates, "The Effects of Air Pollution on Children," Environ. Health Perspect., vol. 103, no. 6, pp. 49-53, 1995.

[15] WHO, "Ambient (outdoor) air pollution," 2021. https://www.who.int/news-room/factsheets/detail/ambient-(outdoor)-air-qualityand-health (accessed Sep. 25, 2021).

[16] M. L. Bell, A. Zanobetti, and F. Dominici, "Evidence on vulnerability and susceptibility to health risks associated with short-term exposure to particulate matter: a systematic review and meta-analysis.," Am. J. Epidemiol., vol. 178, no. 6, pp. 865-876, 2013, doi: 10.1093/aje/kwt090.

[17] L. A. Darrow, M. Klein, W. Dana Flanders, J. A. Mulholland, P. E. Tolbert, and M. J. Strickland, "Air pollution and acute respiratory infections among children 0-4 years of age: An 18-year time-series study," Am. J. Epidemiol., vol. 180, no. 10, pp. 968977, 2014, doi: 10.1093/aje/kwu234.

[18] N. L. Fleischer et al., "Outdoor air pollution, preterm birth, and low birth weight: Analysis 
of the world health organization global survey on maternal and perinatal health," Environ. Health Perspect., vol. 122, no. 4, pp. 425-430, 2014, doi: 10.1289/ehp.1306837.

[19] H. Choi, V. Rauh, R. Garfinkel, Y. Tu, and F. P. Perera, "Prenatal exposure to airborne polycyclic aromatic hydrocarbons and risk of intrauterine growth restriction," Environ. Health Perspect., vol. 116, no. 5, pp. 658665, 2008, doi: 10.1289/ehp.10958.

[20] M. Pedersen et al., “Ambient air pollution and low birthweight: A European cohort study (ESCAPE)," Lancet Respir. Med., vol. 1, no. 9, pp. 695-704, 2013, doi: $10.1016 / \mathrm{S} 2213-2600(13) 70192-9$.

[21] K. Schwab, "The Fourth Industrial Revolution: what it mean, how to respond," World Economic Forum, 2016. https://www.weforum.org/agenda/2016/01/th e-fourth-industrial-revolution-what-it-meansand-how-to-respond/ (accessed Sep. 25, 2021).

[22] J.-P. Tricoire and F. Starace, "These 3 element are crucial to the future of electric cars," World Economic Forum, 2018. https://www.weforum.org/agenda/2018/02/m obility-future-electric-cars-fourth-industrialrevolution/.

[23] USEPA, "Explaining Electric \& Plug-In Hybrid Electric Vehicles." https://www.epa.gov/greenvehicles/explainin g-electric-plug-hybrid-electric-vehicles (accessed Sep. 25, 2021).

[24] E. F. Choma, J. S. Evans, J. K. Hammitt, J. A. Gómez-ibáñez, and J. D. Spengler, "Assessing the health impacts of electric vehicles through air pollution in the United States," Environ. Int., vol. 144, no. February, p. $106015, \quad 2020, \quad$ doi: 10.1016/j.envint.2020.106015.

[25] Z. Hausfather, "Factcheck: How electric vehicles help to tackle climate change," Carbon Brief Clean on Climate, 2019. https://www.carbonbrief.org/factcheck-howelectric-vehicles-help-to-tackle-climatechange (accessed Sep. 25, 2021).

[26] S. R. Choundhury, “Are electric cars 'green'? The answer is yes, but it's complicated," Jul. 2021.
[27] Transport Energy Strategies, "National EV Policies around the World," 2019. https://www.transportenergystrategies.com/2 019/06/26/national-ev-policies-around-theworld/.

[28] J. C. Adiatama, I. Marciano, E. Mursanti, M. Citraningrum, and P. Simamora, Peranan Kendaraan Listrik dalam Dekarbonisasi Sektor Transportasi Darat Indonesia, I. Jakarta: Institue for Essential Services Reform (IESR), 2020.

[29] CNN Indonesia, "7 Regulasi yang bikin kendaraan listrik 'ngebut' di Indonesia," 2020, Jakarta, Oct. . 